\title{
PEMERIKSAAN KUALITAS AIR MINUM ISI ULANG SECARA MIKROBIOLOGIS
}

\section{MICROBIOLOGICAL TEST OF REFILL DRINKING WATER QUALITY}

\author{
Rahmiati* \\ Program Studi Biologi, Fakultas Biologi, Universitas Medan Area \\ Diterima: Maret 2020; Disetujui: Maret 2020; Dipublish: Maret 2020 \\ *Coresponding Email: rahmiati0405@gmail.com
}

\begin{abstract}
Abstrak
Air minum merupakan kebutuhan esensial bagi manusia. Sebanyak 70\% komposisi tubuh manusia adalah air. Air minum dibutuhkan untuk memenuhi asupan cairan tubuh agar terhindar dari dehidrasi. Manfaat lainnya adalah menjaga kesehatan kulit, melindungi saraf dan jaringan tubuh. Salah satu sumber air siap minum yang banyak dikonsumsi masyarakat adalah air minum isi ulang. Penelitian ini bertujuan untuk mengetahui kualitas air minum isi ulang secara mikrobiologis. Penelitian dilaksanakan di Laboratorium Biologi Universitas Medan Area dengan metode most probable number (MPN). Sampel penelitian berasal dari 5 sumber air minum isi ulang di Kecamatan Medan Selayang Kota Medan. Tiga tahapan penting dalam penelitian yaitu uji pendugaan, uji penegasan dan uji lengkap. Hasil penelitian menunjukkan bahwa 40\% sampel air minum isi ulang positif mengandung bakteri coliform fecal dan Eschericia coli.
\end{abstract}

Kata Kunci: air minum, mikrobiologis, most probable number, Escherichia coli.

\begin{abstract}
Drinking water is an essential requirement for humans. As much as $70 \%$ of the composition of the human body is water. Drinking water is needed to meet the intake of body fluids to avoid dehydration. Other benefits are maintaining healthy skin, protecting nerves and body tissues. One source of ready-to-drink water that many people consume is refill drinking water. This study aims to determine the quality of drinking water refill microbiologically. The study was conducted at the Biology Laboratory of the University of Medan Area with the most probable number (MPN) method. The research sample came from 5 refill drinking water sources in Medan Selayang District, Medan City. Three important stages in the study are the estimation test, the affirmation test and the complete test. The results showed that $40 \%$ of positive refill drinking water samples contained fecal coliform bacteria and Escherichia coli.
\end{abstract}

Keywords: drinking water, microbiological, most probable number, Escherichia coli.

How to Cite: Rahmiati. (2020). Pemeriksaan Kualitas Air Minum Isi Ulang Secara Mikrobiologis. Journal of Natural Sciences. Vol 1 (1): 31-37 
Rahmiati. Pemeriksaan Kualitas Air Minum Isi Ulang Secara Mikrobiologis

\section{PENDAHULUAN}

Air merupakan kebutuhan esensial bagi manusia. Sebanyak 70\% komposisi tubuh manusia adalah air. Air minum dibutuhkan untuk memenuhi asupan cairan tubuh agar terhindar dari dehidrasi. Sejalan dengan peningkatan taraf hidup, maka jumlah kebutuhan air juga akan semakin besar. Salah satu cara untuk memenuhi kebutuhan air tersebut adalah dengan mencari dan melakukan pengadaan sumber air baru, diantaranya mencari sumber-sumber air baru, baik berbentuk air tanah, air sungai, air danau. Melakukan pengolahan air laut menjadi tawar dan siap pakai dan mengolah sumber air kotor yang telah tercemar (Widiyanti, 2004).

Di wilayah perkotaan, sering kali terjadi kelangkaan air tawar bersih yang menjadi bahan baku utama sumber air minum. Pencemaran sungai oleh limbah domestik dan limbah beracun dari industri mengurangi keberadaan sumber air bersih. Adanya rembesan dari tangki septik tank membuat air tanah maupun air permukaan juga tidak lagi aman sebagai sumber air bersih. Salah satu cara untuk mendapatkan air siap minum yang bersih dan steril adalah dengan mengkonsumsi air minum dalam kemasan. Harga air minum dalam kemasan yang mahal menjadi kendala untuk sebagian masyarakat berpenghasilan rendah. Hal ini menjadi alasan masyarakat beralih ke air minum isi ulang. Selain harganya murah, sumber air ini juga mudah diperoleh (Radji et al, 2008).

Pemeriksaan kulaitas air minum isi ulang penting untuk dilakukan. Pengujian kualitas air minum isi ulang menggunakan menggunakan pengujian Most Probable Number (MPN) untuk mendeteksi keberadaan bakteri coliform fecal dan keberadaan Eschericia coli. Bakteri coliform adalah bakteri yang dapat digunakan sebagai indikator untuk menentukan kualitas sumber air yang terkontaminasi. Keberadaan bakteri ini pada minuman mengindikasikan bahwa makanan tersebut pernah tercemar oleh tinja (Putri \& Kurnia, 2018).

Penelitian ini dilakukan untuk mendapatkan gambaran akan kualitas air minum isi ulang di lima depo air minum isi ulang di kecamatan Medan Selayang, Kota Medan. Hasil penelitan diharapkan dapat memberikan manfaat baik bagi Dinas Kesehatan setempat untuk melakukan pengawasan secara berkala terhadap kualitas air minum isi ulang, maupun bagi masyarakat sebagai konsumen air minum isi ulang dan para pemilik depo air minum isi ulang agar dapat melakukan pemeliharaan dan perbaikan secara terus menerus dalam penanganan dan pengolahan air minum isi ulang secara baik, sehingga 
terhindar dari pencemaran mikroba sebagai upaya untuk melindungi kesehatan masyarakat.

\section{METODE PENELITIAN}

\section{Sampel Penelitian}

Sampel penelitian diperoleh dari 5 depo air minum isi ulang di kecamatan Medan Selayang, Kota Medan. Sampel diambil sebanyak $1000 \mathrm{ml}$ secara aseptis, dimasukkan ke dalam botol winkler steril. Selanjutnya dilakukan pemeriksaan di Laboratorium.

\section{Pengujiam Kualitas Air Minum secara Mikrobiologis}

Pengujian kualitas air minum secara mikrobiologis dilakukan dengan metode most probable number (MPN), dengan 3 tahapan uji yaitu uji pendugaan, uji penegasa dan uji lengkap.

\section{Uji Pendugaan}

Disiapkan sebanyak 9 tabung reaksi yang didalamnya telah dimasukkan tabung durham dalam posisi terbalik. Dimasukkan media Lactose Broth (LB) steril ke dalam masing - masing tabung tersebut secara aseptis dengan jumlah yaitu $10 \mathrm{ml}$ untuk 3 seri tabung pertama, $1 \mathrm{ml}$ untuk 3 seri tabung kedua dan 0,1 $\mathrm{ml}$ untuk 3 seri tabung ketiga. Diinkubasi seluruh tabung selama 24 jam pada suhu $35^{\circ} \mathrm{C}$. Diamati gelembung gas yang terbentuk pada tabung durham disetiap tabung reaksi. Dihitung nilai MPN koliform melalui tabel indeks MPN.

\section{Uji penegasan}

Disiapkan tabung reaksi yang didalamnya telah dimasukkan tabung durham dalam posisi terbalik. Jumlah tabung reaksi disesuaikan dengan jumlah tabung positif pada uji Pendugaan. Dimasukkan media Brillian Green Lactose Bile Broth (BGLBB) steril secara aseptis. Diambil $0,1 \mathrm{ml}$ tiap media yang menunjukkan uji positif pada uji pendugaan, dan diinokulasikan ke media uji. Diikubasi selama 24 jam pada suhu $35^{\circ} \mathrm{C}$. Diamati gelembung gas yang terbentuk pada tabung durham disetiap tabung reaksi. 
Rahmiati. Pemeriksaan Kualitas Air Minum Isi Ulang Secara Mikrobiologis

\section{Uji lengkap}

Disiapkan petri yang telah berisi media Eosin Metylen Blue (EMB). Dicelupkan satu ose kedalam tabung reaksi yang menunjukkan uji positif pada uji sebelumnya. Digoreskan ose tersebut pada media EMB. Diinkubasi selama 24 jam pada suhu $35^{\circ} \mathrm{C}$. dilihat koloni bakteri yang terbentuk.

\section{HASIL DAN PEMBAHASAN}

Pemeriksaan kualitas air minum dilakukan dengan tiga tahapan utama yaitu uji pendugaan, penegasan dan uji lengkap. Hasil pengujian dengan metode MPN pada uji pendugaan tersaji pada tabel 1 berikut ini.

Tabel 1. Hasil uji MPN pada tahapan pendugaan sampel air minum isi ulang

\begin{tabular}{cccccc}
\hline \multirow{2}{*}{ Sampel } & \multicolumn{3}{c}{ Nomor tabung positif } & & Nilai \\
& $10 \mathrm{ml}$ & $1 \mathrm{ml}$ & $0,1 \mathrm{ml}$ & MPN/100 ml & Keterangan \\
\cline { 2 - 4 } & 0 & 0 & 0 & 0 & Tidak dilanjutkan \\
AM01 & 2 & 1 & 1 & 20 & Dilanjutkan \\
AM02 & 2 & 0 & 0 & 9 & Dilanjutkan \\
AM03 & 2 & 1 & 0 & 15 & Dilanjutkan \\
AM04 & 2 & 2 & 1 & 28 & Dilanjutkan \\
AM05 & & & & &
\end{tabular}

Uji pendugaan bertujuan untuk mengetahui keberadaan bakteri coliform pada sampel air minum isi ulang. Berdasarkan tabel 1 diketahui bahwa 4 dari total 5 sampel mengandung bakteri coliform dengan jumlah bakteri berdasarkan nilai indeks MPN yang bervariasi. Nilai MPN tertinggi pada sampel AM05 dan AM02 masing - masing sebesar 20 dan 28 koloni bakteri/100 ml air minum isi ulang. Keberadaan bakteri coliform pada sampel air minum isi ulang menunjukkan tingkat sanitasi dan kebersihan air minum isi ulang yang masih minim. Sanitasi yang kurang baik dari penjamah makanan atau penjual dapat menjadi sumber penyakit bagi konsumen dan dapat menyebar kepada masyarakat (Falamy et al, 2012).

Beberapa faktor yang dapat mempengaruhi kualitas produk air minum yang dihasilkan adalah air sebagai bahan baku, tingkat kebersihan operator, sterilisasi dan penanganan kebersihan terhadap wadah pembeli, dan kondisi depot air minum isi ulang. Faktor lain yang juga menentukan kualitas air minum isi ulang antara lain adalah kebersihan operator dalam menangani konsumen dan wadah isi ulang air minum. Salah satu bentuk aplikasi kebersihan yang paling mudah diterapkan adalah kegiatan mencucui tangan oleh operator sebelum menangani wadah air minum isi ulang. Hal ini dilakukan 
untuk memperkecil resiko kontaminasi bakteri (Suriawiria 2008; Afif \& Endrinaldi, 2015). Salah satu bentuk menjaga kebersihan diri sendiri adalah dengan mencuci tangan sebelum menangani wadah yang dibawa konsumen, gunanya adalah untuk mengurangi kemungkinan terjadinya kontaminasi.

Deteksi keberadaan bakteri coliform dilakukan dengan melihat uji positif setelah masa inkubasi. Media uji yang positif akan mengahsilkan gas yang terperangkap di dalam tabung durham, selain itu, warna media juga akan menjadi keruh. Adanya gelembung gas sebagai akibat dari fermentasi laktosa pada media oleh bakteri coliform. Sementara kekeruhan media menunjukkan bahwa ada pertumbuhan bakteri.

Tabel 2. Hasil Uji Penegasan sampel air minum isi ulang

\begin{tabular}{ccl}
\hline Sampel & Hasil uji & \multicolumn{1}{c}{ Keterangan } \\
\hline AM02 & $\sqrt{ }$ & $\begin{array}{l}\text { Positif mengandung bakteri coliform fecal (dilanjutkan ke } \\
\text { uji lengkap) }\end{array}$ \\
AM03 & - & $\begin{array}{l}\text { Negatif mengandung bakteri coliform fecal } \\
\text { dilanjutkan ke uji lengkap) } \\
\text { Negatif mengandung bakteri coliform fecal (tidak } \\
\text { dilanjutkan ke uji lengkap) } \\
\text { Positif mengandung bakteri coliform fecal (dilanjutkan ke } \\
\text { uji lengkap) }\end{array}$ \\
\hline
\end{tabular}

Tahap kedua dari uji MPN adalah uji penegasan. Uji penegasan merupakan uji lanjutan untuk mendeteksi keberadaan bakteri coliform fecal dari sampel air minum isi ulang. Berdasarkan tabel 2 dapat diketahui bahwa, sampel air minum isi ulang AM02 dan AM05 positif mengandung bakteri coliform fecal.

Bekteri coliform merupakan bakteri berbentuk basil yang termasuk bakteri intestinal, yaitu hidup didalam saluran pencernaan manusia. Bakteri coliform fecal biasanya berasal dari tinja. Bakteri coliform fecal merupakan bakteri indicator pencemaran bakteri patogen. Penentuan coliform fekal menjadi indicator pencemaran dan indicator kulaitas air dikarenakan jumlah koloninya pasti berkorelasi positif dengan keberadaan bakteri patogen. Contoh bakteri coliform yaitu Escherichia coli dan Enterobacter aerogenes. Semakin sedikit kandungan coliform di dalam sampel air, maka dapat dinyatakan kualitas air semakin baik (Surono, 2018).

Proses fermentasi laktosa yang terdapat pada media uji lactose broth terjadi karena adanya aktifitas bakteri coliform fecal yaitu Escherichia coli. Fermentasi gula akan menghasilkan asam piruvat dan asam asetat. Reaksi anaerobic ini akan memunculkan 3. 
Rahmiati. Pemeriksaan Kualitas Air Minum Isi Ulang Secara Mikrobiologis

gelembung gas CO2 yang selanjutnya akan mendesak ruang tabung durham yang berada dalam posisi terbalik. Jika dalam waktu lebih dari 24 jam maka akan semakin banyak ruang gas yang akan terbentuk pada tabung durham pada reaksi yang positif. Reaksi negatif tidak menunjukkan adanya keberadaan bakteri ditandai dengan tidak terbentuknya gelembung gas pada tabung durham (Kusuma, 2009; Putri \& Kurnia, 2018). Tabel 3. Hasil uji Lengkap deteksi keberadaan bakteri Eschericia coli

\begin{tabular}{ccl}
\hline Sampel & Hasil uji & \multicolumn{1}{c}{ Keterangan } \\
\hline AM02 & $\sqrt{ }$ & $\begin{array}{l}\text { Terdapat koloni bakteri hijau metalik pada media uji } \\
\text { (positif E. coli) } \\
\text { AM05 }\end{array}$ \\
$\sqrt{ }$ & $\begin{array}{l}\text { Terdapat koloni bakteri hijau metalik pada media uji } \\
\text { (positif E. coli) }\end{array}$ \\
\hline
\end{tabular}

Bakteri Escehricia coli merupakan indikator kebersihan dan kemanan konsumsi air minum. Deteksi keberadaan bakteri ini dilakukan dengan menginokulasikans sampel ke dalam media uji selektif Eosin Metylen Blue. Media uji ini mengandung eosin yang akan menghambat pertumbuhan bakteri gram positif, dan menyokong pertumbuhan bakteri gram positif. Uji positif terhadap pertumbuhan E. coli yaitu pertumbuhan koloni berwarna hijau metalik mengkilap. Warna koloni bakteri terbentuk karena adanya mekanisme berfluoresensi atau memancarkan cahaya sehingga menghasilkan kilap logam atau metalik, dan terjadi reaksi antara methylen blue dan bakteri E. coli (Bambang et al, 2014; Puspitasari et al, 2015). Beberapa penelitian menyatakan bahwa bakteri probiotik seperti bakteri asam laktat memiliki kemampuan dalam menghambat pertumbuhan E. coli melalui mekanisme antagonistic dan melalui metabolit yang dihasilkannya seperti bakteriosin (Rahmiati \& Mumpuni, 2017).

\section{SIMPULAN}

Berdasarkan penelitian yang dilakukan dapat disimpulkan bahwa sebanyak $40 \%$ dari total sampel air minum isi ulang positif mengandung bakteri Eshericia coli yaitu sampel AM02 dan AM05. Sampel penelitian dengan kode AM01 tidak mengindikasikan adanya keberadaan bakteri coliform sehingga aman untuk dikonsumsi. Sangat penting untuk menjaga kebersihan perlatan yang digunakan dan kebersihan pekerja agar tidak terjadi kontaminasi pada air minum isi ulang. 


\section{DAFTAR PUSTAKA}

Afif F, Erly \& Endrinaldi. (2015). Identifikasi Bakteri Eschericia coli pada Air Minum Isi Ulang yang Diproduksi Depot Air Minum Isi Ulang Di Kecamatab Padang Selatan. Jurnal Kesehatan Andalas. 4(2): $376-380$.

Bambang AG, Fatimawali \& Kojong N S. (2014). Analisis Cemaran Bakteri Coliform dan Identifikasi Escherichia coli pada Air Isi Ulang Dari Depot di Kota Manado. Pharmacon Jurnal Ilmiah Farmasi. 3(3): $325-334$.

Falamy R, Warganegara E \& Apriliana E. (2012). Deteksi Bakteri Coliform pada Jajanan Pasar Cincau Hitam di Pasar Tradisional dan Swalayan Kota Bandar Lampung. Majority Medical Jornal of Lampung University. 1(1): 1 - 9.

Kusuma SAF. (2009). Uji Biokimia Bakteri. Artikel Ilmiah. Fakultas Farmasi Universitas Padjajaran Bandung.

Puspitasari I, Indriyanti N, Yulita V \& Rusli R. (2015). Pengujian Kualitas Aspek Mikrobiologi Air Minum Isi Ulang. Prosiding Seminar Nasional Kefarmasian I. 1 - 8.

Putri MA \& Kurnia P. (2018). Identifikasi Keberadaan Bakteri Coliform dan Total Mikroba dalam Es Dung Dung di Sekitar Kampus Universitas Muhammadiyah Surakarta. Media Gizi Indonesia. 13(1): 40 $-48$.

Radji M, Oktavia H \& Suryadi H. (2008). Pemeriksaan Bakteriologis Air Minum Isi Ulang di Beberapa Depo Air Minum Isi Ulang di Daerah Lenteng Agung Jakarta Selatan. Majalah Ilmu Kefarmasian. 5(2): $101-109$.

Rahmiati \& Mumpuni M. (2017). Eksplorasi Bakteri Asam Laktat Kandidat Probiotik dan Potensinya Dalam Menghambat Bakteri Patogen. Elkawnie. 3(2): 141 - 150.

Suriawiria. (2008). Mikrobiologi Air dan Dasar - Dasar Pengolahan secara Biologis. Bandung: Penerbit Alumni.

Surona IS, Sudibyo A \& Waspodo P. (2018). Pengantar Keamanan Pangan untuk Industri Pangan. Deepublish CV Budi Utama: Yogyakarta.

Widiyanti I PM \& Ristiati NP. (2004). Analisis Kualitas Bakteri Koliform pada Depo Air Minum Isi Ulang di Kota Singaraja Bali. Jurnal Ekologi Kesehatan. 3(1): 64 - 73. 